\title{
Correction: UK tobacco price increases: driven by industry or public health?
}

Hiscock R, Branston JR, Partos TR, et al. UK tobacco price increases: driven by industry or public health?.Tob Control 2019;28:e148-50.doi:10.1136/tobaccocontrol-2019-054969.

In the original article there was an error in the calculation of Value Added Tax (VAT). We calculated the VAT sales tax that is applicable to tobacco sales in the UK as a proportion of the final sales price rather than as a proportion of the pre-VAT price, leading to a slight overestimation of the size of the tax and hence an underestimation of the industry's revenues. This error does not change the fundamental result or substance of the paper. For instance, we originally estimated the total tax increase of a 20 stick packet of premium cigarettes between 2013-15 was $£ 0.76$, but we now know it should in fact have been $£ 0.71$ due to our inadvertent over-estimation of the VAT due. The impact of this was that industry revenue actually increased by $£ 0.58$ as opposed to the original estimate of $£ 0.53$. The split between tax/industry source of the price increase therefore changed from our original estimate of $59 \% \operatorname{tax} 41 \%$ industry price rises, to $55 \% / 45 \%$.

The results section therefore should read as follows:

\section{RESULTS}

In 2010-2012, the proportion of the price increase attributable to tax increases and industry price/revenue increases did not differ substantially by price segment or product type (despite tax and price increases being greater, in absolute terms, for FM than for RYO). For both FM and RYO increases in industry revenue accounted for about a quarter of the total price increase with little variation (20\%-28\%), and government revenues for the remainder ( 75\%).

In 2013-2015, however, the patterns were quite different. First, government tax, industry revenue and total price increases varied much more substantially by price segment. Larger absolute tax and price increases were seen in higher price segments for both FM and RYO. Furthermore, the impact of the differential tax increases was exacerbated by industry actions, with the industry adding 58 pence to the price of FM premium brands but cutting subvalue brands' prices by four pence, and in RYO adding 36 pence to RYO premium but only 16 pence to RYO value. Consequently, a nearly two-fold difference in tax increase (41p (FM subvalue) to $71 \mathrm{p}$ (FM premium)) translates to a more than threefold difference in price increase ( $37 \mathrm{p}$ to $£ 1.29$, respectively) between FM segments. The percentage increase in overall total FM and overall total RYO price attributable to increases in industry revenue was higher in this period than the previous period. On average, about a third of the price increase for FM was industry revenue (compared with $23 \%$ in the previous period), while about half of the increase for RYO was industry revenue (compared with $27 \%$ in previous period).

A revised table 1 is presented below:

Table 1 Weighted Real price changes in pack revenue and tax-popular pack sizes in UK 2010-2015

\begin{tabular}{|c|c|c|c|c|c|}
\hline & $\begin{array}{l}\text { Total price } \\
\text { increase }\end{array}$ & $\begin{array}{l}\text { Government tax } \\
\text { increase }\end{array}$ & $\begin{array}{l}\text { Tobacco industry } \\
\text { revenue increase }\end{array}$ & $\begin{array}{l}\% \text { of price change that } \\
\text { is government tax }\end{array}$ & $\begin{array}{l}\% \text { of price change that is } \\
\text { tobacco industry revenue }\end{array}$ \\
\hline \multicolumn{6}{|l|}{ Jan 2010 to Dec $2012^{*}$} \\
\hline FM premium 20 stick & $£ 0.91$ & $f 0.67$ & f0.24 & $74 \%$ & $26 \%$ \\
\hline FM mid price 20 stick & f0.96 & $£ 0.74$ & $f 0.22$ & $77 \%$ & $23 \%$ \\
\hline FM value 20 stick & f1.12 & $£ 0.87$ & $£ 0.25$ & $78 \%$ & $22 \%$ \\
\hline FM value 19 stick & £0.95 & $\mathrm{f} 0.70$ & f0.19 & $80 \%$ & $20 \%$ \\
\hline Total FM† & & & & $77 \%$ & $23 \%$ \\
\hline RYO premium $12.5 \mathrm{~g}$ & f0.58 & $£ 0.43$ & f0.14 & $75 \%$ & $25 \%$ \\
\hline RYO mid price $12.5 \mathrm{~g}$ & $\mathrm{f} 0.60$ & $£ 0.43$ & $\mathrm{f} 0.17$ & $72 \%$ & $28 \%$ \\
\hline RYO value $12.5 \mathrm{~g}$ & f0.55 & $f 0.42$ & f0.13 & $76 \%$ & $24 \%$ \\
\hline Total RYO† & & & & $73 \%$ & $27 \%$ \\
\hline \multicolumn{6}{|l|}{ Jan 2013 to Dec $2015 \ddagger$} \\
\hline FM premium 20 stick & f1.29 & $£ 0.71$ & $f 0.58$ & $55 \%$ & $45 \%$ \\
\hline FM mid price 20 stick & f1.08 & $£ 0.66$ & 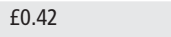 & $61 \%$ & $39 \%$ \\
\hline FM value 19 stick & $£ 0.83$ & $£ 0.60$ & $£ 0.23$ & $73 \%$ & $27 \%$ \\
\hline FM sub value 19 stick & f0.37 & $£ 0.41$ & $-f 0.04$ & $112 \%$ & $-12 \%$ \\
\hline Total FM† & & & & $64 \%$ & $36 \%$ \\
\hline RYO premium $12.5 \mathrm{~g}$ & $£ 0.64$ & $£ 0.28$ & $f 0.36$ & $44 \%$ & $56 \%$ \\
\hline RYO mid price $12.5 \mathrm{~g}$ & $£ 0.55$ & $f 0.26$ & $\mathrm{f} 0.28$ & $48 \%$ & $52 \%$ \\
\hline RYO value $12.5 \mathrm{~g}$ & f0.39 & $\mathrm{f} 0.24$ & $\mathrm{f} 0.16$ & $61 \%$ & $39 \%$ \\
\hline
\end{tabular}




\begin{tabular}{cccc}
\hline & $\begin{array}{l}\text { Total price } \\
\text { increase }\end{array}$ & $\begin{array}{l}\text { Government tax } \\
\text { increase }\end{array}$ & $\begin{array}{l}\text { Tobacco industry } \\
\text { revenue increase of price change that } \begin{array}{l}\% \text { of price change that is } \\
\text { tobacco industry revenue }\end{array}\end{array}$ \\
\hline Total RYOt & & $48 \%$ & $52 \%$ \\
\hline
\end{tabular}

${ }^{*}$ As of 31 March $2011 \mathrm{f} 1=\mathrm{US} \$ 1.603 .21$.

†As of 31 March $2014 \mathrm{f} 1=\mathrm{US} \$ 1.6672 .22$

¥Weighted for volume, popular pack sizes only.

FM, factory-made cigarettes; RYO, roll-your-own tobacco.

\section{OPEN ACCESS}

Open access This is an open access article distributed in accordance with the Creative Commons Attribution Non

Commercial (CC BY-NC 4.0) license, which permits others to distribute, remix, adapt, build upon this work non-commercially, and license their derivative works on different terms, provided the original work is properly cited, appropriate credit is given, any changes made indicated, and the use is non-commercial. See: http://creativecommons.org/licenses/by-nc/4.0/.

(C) Author(s) (or their employer(s)) 2020. Re-use permitted under CC BY-NC. No commercial re-use. See rights and permissions. Published by BMJ.

Tob Control 2020;0:1-2. doi:10.1136/tobaccocontrol-2019-054969corr1

D) Check for updates 